\title{
ANALISIS RASIO LIKUIDITAS PADA PT. BANK PERKREDITAN RAKYAT (BPR) LENGAYANG
}

\author{
Mediana Badria, Doni Marlius \\ Akademi Keuangan dan Perbankan Padang \\ medianabadrianew@gmail.com \\ donimarlius@akbpstie.ac.id
}

\begin{abstract}
The purpose of this study was to find out how the liquidity ratio of PT. BPR Lengayang. The research method used is the method of data analysis qualitative and quantitative. The type of data used is secondary data obtained from Bank Indonesia and rural banks (BPR) publication reports for the period 2013-2017. The results of this study indicate that the bank CR level is in a healthy position. The QR level also indicates that the bank is in a healthy condition, meaning that the bank is able to pay its short-term debt by using liquid assets owned by the bank. In the LDR position in 2013-2014 the bank was in an unhealthy position, but in the following year the bank always experienced changes that were getting better, so that in 2015-2017 the bank was in a healthy position.
\end{abstract}

Keywords :Liquidity, $C R, Q R$, and $L D R$

\section{PENDAHULUAN}

Pertumbuhan ekonomi suatu negara dipengaruhi oleh banyak faktor, diantaranya yaitu di bidang perbankan memiliki fungsi pokok sebagai lembaga penghimpunan dana masyarakat. Menurut Undang-undang RI No.10 Tahun 1998 tentang perbankan, bank merupakan badan usaha menghimpun dana dari masyarakat dalam bentuk simpanan dan menyalurkannya kembali dalam bentuk kredit dan atau bentuk lainnya dalam rangka meningkatkan taraf hidup rakyat banyak.

Dalam Undang-undang RI No.10 Tahun 1998 tentang perbankan, menurut jenisnya Bank dibagi menjadi dua yakni, Bank Umum merupakan bank yang manjalankan usaha secara konvensional atau berdasarkan prinsip syariah yang kegiatannya memberikan jasa dalam lalu lintas pembayaran. Sedangkan Bank Perkreditan Rakyat merupakan bank yang melaksanakan usaha secara konvensional atau berdasarkan prinsip syariah yang kegiatannya tidak memberikan jasa dalam lalu lintas pembayaran.

Keberadaan BPR di Indonesia mampu menunjukan perannya dalam memberikan jasa kepada usaha kecil dan menengah, karena BPR diarahkan untuk melayani usaha kecil dari masyarakat di perdesaan dan juga untuk memenuhi kebutuhan masyarakat dalam bidang keuangan dengan ketentuan yang lebih mudah dibandingkan dengan bank umum. supaya dapat menjalankan tugas pokok dan mempertahankan kelangsungan BPR, kepercayaan masyarakat sangat penting dan memperoleh gambaran tentang perkembangan kuangan suatu bank, perlu 
mengadakan analisa terhadap data keuangan dari bank yang bersangkutan dimana data tersebut dapat dilihat dalam laporan keuangan.

Menurut Tanor, Dkk (2015) Laporan keuangan adalah hasil proses akuntansi yang dipakai sebagai alat mengkomunikasikan data keuangan kepada pihak yang berkepentingan. Laporan keuangan yang dikenal adalah Neraca, Laporan Laba Rugi atau Hasil Usaha, Laporan Perubahan Ekuitas, Laporan Arus Kas, serta Laporan Posisi Keuangan (Ottay \& Alexander, 2015).

Laporan keuangan perlu dianalisis untuk mengevaluasi kinerja yang dicapai manajemen perusahaan di masa lalu, dan sebagai bahan pertimbangan dalam menyusun rencana perusahaan ke depannya dengan menggunakan analisis rasio. Analisis rasio adalah cara yang digunakan dalam menganalisis laporan keuangan perusahaan. Salah satu analisis rasio yang digunakan yaitu rasio likuiditas. Rasio likuiditas yaitu rasio untuk mengukur kemampuan dalam membayar utang jangka pendeknya pada saat ditagih perusahaan lain.

Likuiditas adalah kesanggupan bank memenuhi penarikan dana oleh para nasabah deposan, kewajiban jatuh tempo dan memenuhi permintaan kredit tanpa penundaan (Anggraeni \& Dkk, 2014). Menurut Rahmayeli \& Marlius (2015) Rasio Likuiditas Yaitu mendeskripsikan perusahaan untuk menyelesaikan kewajiban jangka pendeknya. Rasio likuiditas yakni kesanggupan bank dalam memenuhi kebutuhan likuiditas yang harus dipenuhi, atau kesanggupan bank untuk mencukupi kewajiban keuangan jangka pendek (Saputro, 2009). Rasio likuiditas dapat diukur dengan beberapa rasio keuangan seperti Cash Ratio (CR), Quick Ratio (QR), dan Loan to Deposit Ratio (LDR) (Yusra, 2016).

Menurut Susanto \& Kholis (2016) Cash Ratio merupakan likuiditas minimum yang harus dipelihara oleh bank dalam membayar kembali pinjaman jangka pendek bank. Sedangkan menurut Ramadaniar, Dkk (2013) Quick Ratio adalah rasio yang dipergunakan mengukur kemampuan bank dalam memenuhi kewajibannya terhadap para deposan. dengan harta likuid yang dimiliki bank.

Loan to Deposit Ratio (LDR) digunakan menilai kemampuan suatu bank dalam memenuhi kewajiban dalam jangka pendek terhadap pihak ketiga melalui kredit yang disalurkan (Afriyeni, 2017).

Sebagai lembaga yang dipercaya oleh masyarakat maka bank wajib mengelola likuiditasnya secara efektif terutama untuk mengurangi risiko likuiditas yang diakibatkan karena bank tersebut mengalami kekurangan dana dalam melunasi kewajiban jangka pendeknya. Dalam penelitian ini juga dapat diketahui seberapa mampu harta yang dimiliki oleh perusahaan tersebut dalam menutupi kewajiban jangka pendeknya pada saat jatuh tempo. Suatu perusahaan dapat dinyatakan likuid apabila perusahaan sanggup untuk melunasi utang jangka pendeknya saat jatuh tempo dan apabila perusahaan tidak sanggup untuk melunasi utang jangka pendeknya saat jatuh tempo, maka perusahaan dapat dinyatakan tidak likuid.

PT. BPR Lengayang merupakan salah satu BPR yang ada di Pesisir Selatan. BPR ini perlu memperhatikan tingkat Likuiditasnya dalam membayar utang jangka pendek dengan menggunakan aktiva lancar yang dimiliki oleh bank tersebut. Berikut data keuangan yang digunakan untuk mengetahui perkembangan likuiditas PT. BPR Lengayang. 
Tabel 1

Data keuangan PT. BPR Lengayang

Tahun 2013-2017

\begin{tabular}{|c|c|c|c|c|c|}
\hline & & & & \multicolumn{2}{|c|}{ (Dalam Juta Rupiah) } \\
\hline keterangan & 2013 & 2014 & 2015 & 2016 & 2017 \\
\hline Alat Likuid & 2.272 .446 & 4.717 .986 & 5.454 .021 & 6.650 .475 & $10.529 .76 \mathrm{I}$ \\
\hline $\begin{array}{l}\text { Kewajiban } \\
\text { Segera }\end{array}$ & 66.684 & 133.160 & 79.436 & 76.010 & 379.498 \\
\hline $\begin{array}{l}\text { Kredit Yang } \\
\text { Diberikan }\end{array}$ & 25.903 .700 & 25.955 .264 & 26.587.912 & 28.451 .020 & 31.748 .298 \\
\hline $\begin{array}{l}\text { Dana Pihak } \\
\text { Ketiga }\end{array}$ & 16.981 .090 & 19.052 .091 & 23.677 .558 & 28.343 .930 & 34.334 .604 \\
\hline Modal & 3.501 .500 & 3.617 .000 & 3.617 .000 & 3.817 .000 & 5.217 .000 \\
\hline
\end{tabular}

Sumber : Laporan Keuangan PT. BPR Lengayang

Berdasarkan tabel 1 Dapat diketahui bahwa neraca PT. BPR Lengayang pada posisi likuiditas selalu mengalami kenaikan setiap tahunnya kecuali pada posisi kewajiban segera yang masih berfluktuasi. Hal ini dapat dilihat pada posisi kewajiban segera pada tahun 2013 (Rp. 66.684) dan tahun 2014 (Rp. 133.160) mengalami kenaikan sebesar Rp. 66.476, tahun 2014 (Rp.133.160) ke tahun 2015 (Rp. 79.436) mengalami penurunan sebesar Rp. 53.724, tahun 2015 (Rp. 79.436) ke tahun 2016 (Rp. 76.010) juga mengalami penurunan sebesar Rp. 3.426, sedangkan pada tahun 2016 (Rp. 76.010) ke tahun 2017 (Rp.379.498) kembali mengalami kenaikan sebesar Rp. 303.488.

Berdasarkan uraian tersebut, maka tujuan penelitian ini yaitu untuk mengetahui bagaimana rasio likuiditas yang diukur dari Cash Ratio (CR), Quick Ratio (QR), serta Loan to Deposit Ratio (LDR) pada PT. Bank Perkreditan Rakyat Lengayang dalam periode $2013-2017$.

\section{METODE PENELITIAN}

Metode yang dipakai ialah analisa data kualitatif dan kuantitatif. Dimana metode kualitatif menggambarkan, memahami dan menjelaskan data yang diteliti selama penelitian berlangsung. Sedangkan metode kuantitatif menganalisa perkembangan rasio likuiditas pada PT. BPR Lengayang.

\section{HASIL DAN PEMBAHASAN}

Rasio likuiditas yaitu suatu indikator menilai kemampuan perusahaan dalam melunasi segala kewajiban financial jangka pendeknya saat jatuh tempoh. Secara akuntansi keuangan atau perbankan, pengukuran likuiditas dapat dilakukan dengan perhitungan rasio yang menggambarkan hubungan timbal balik antara asset dan liabilitie.

Menurut Jumingan (2006) rasio likuiditas bertujuan untuk melihat kecukupan dana, kemampuan perusahaan dalam membayar kewajiban yang harus dipenuhi. Yang termasuk rasio likuiditas yaitu Cash Ratio, Quick Ratio, dan Loan to Deposit Ratio. 


\section{Cash Ratio (CR)}

Cash Ratio yaitu rasio alat likuid terhadap dana pihak ketiga yang dihimpun bank dan harus dibayar. Rasio ini dipergunakan untuk menilai kesanggupan bank melunasi kembali simpanan nasabah (deposan) saat ditarik menggunakan alat likuid yang dimilikinya. Menurut ketentuan Bank Indonesia, alat likuid terdiri atas uang kas ditambah dengan rekening giro bank yang disimpan pada Bank Indonesia (Palar \& Dkk, 2013).

Kriteria penilaian Cash Ratio menurut SK DIR BI Nomor : 30/12/KEP/DIR tanggal 30 april 1997 tentang tentang cara penilaian tingkat kesehatan BPR (Taufik, 2012).
a. $>=4,05 \%$
: sehat
b. $>=3,30 \%-<4,05 \%$ : cukup sehat
c. $>=2,55 \%-<3,30 \%$ : kurang sehat
d. $<2,55 \%$
: tidak sehat

Berdasarkan data yang diperoleh Cash Ratio PT. BPR Lengayang tahun 2013 - 2017 dapat dilihat pada tabel dibawah ini.

Tabel 2

Perkembangan Cash Ratio PT. BPR Lengayang

Tahun 2013-2017

(Dalam Juta Rupiah)

\begin{tabular}{cccccc}
\hline Uraian & $\mathbf{2 0 1 3}$ & $\mathbf{2 0 1 4}$ & $\mathbf{2 0 1 5}$ & $\mathbf{2 0 1 6}$ & $\mathbf{2 0 1 7}$ \\
\hline Alat Likuid & & & & & \\
a. Kas & 807.349 & 1.038 .498 & 617.874 & 509.424 & 495.817 \\
b. Antar Bank & 1.465 .097 & 3.679 .488 & 4.836 .147 & 6.141 .051 & 10.033 .944 \\
$\quad$ Aktiva & & & & & \\
$\quad \begin{array}{l}\text { Jumlah } \\
\text { Hutang Lancar }\end{array}$ & $\mathbf{2 . 2 7 2 . 4 4 6}$ & $\mathbf{4 . 7 1 7 . 9 8 6}$ & $\mathbf{5 . 4 5 4 . 0 2 1}$ & $\mathbf{6 . 6 5 0 . 4 7 5}$ & $\mathbf{1 0 . 5 2 9 . 7 6 1}$ \\
$\begin{array}{l}\text { a. Kewajiban } \\
\quad \text { Segera }\end{array}$ & 66.684 & 133.160 & 79.436 & 76.010 & 379.498 \\
$\begin{array}{l}\text { b. Tabungan } \\
\text { c. Deposito }\end{array}$ & 8.560 .274 & 10.046 .391 & 11.495 .058 & 14.060 .430 & 17.961 .404 \\
$\quad$ Jumlah & $\mathbf{1 6 . 9 8 1 . 0 9 0}$ & $\mathbf{1 9 . 0 5 2 . 0 9 1}$ & $\mathbf{2 3 . 6 7 7 . 5 5 8}$ & $\mathbf{2 8 . 3 4 3 . 9 3 0}$ & $\mathbf{3 4 . 3 3 4 . 6 0 4}$ \\
\hline
\end{tabular}

Sumber : Laporan Keuangan PT. BPR Lengayang

Dengan rumus:

$\mathrm{CR}=\frac{\mathrm{AL}}{\mathrm{HL}} \mathrm{X} 100 \%$

Alat Likuid $\quad=$ Kas + Antar Bank Aktiva

Hutang Lancar = Kewajiban Segera + DPK

a. Tahun 2013

$C R=\frac{2.272 .446}{17.047 .774} X 100 \%=13,33 \%$

Artinya, bank mampu membayar utang jangka pendeknya menggunakan alat likuid yang dimiliki oleh bank tersebut dengan CR sebesar 13,33\%. Hal ini menunjukkan bahwa pada tahun 2013 cash ratio bank dikatakan sehat karena besar dari 4,05\%. 
b. Tahun 2014

$$
C R=\frac{4.717 .986}{19.185 .251} X 100 \%=24,59 \%
$$

Artinya, bank mampu memenuhi utang jangka pendeknya menggunakan alat likuid yang dimiliki oleh bank tersebut dengan CR sebesar 24,59\%. Hal ini menunjukkan bahwa pada tahun 2014 cash ratio bank dikatakan sehat karena besar dari 4,05\%.

c. Tahun 2015

$$
C R=\frac{5.454 .021}{23.756 .994} X 100 \%=22,96 \%
$$

Artinya, bank mampu memenuhi utang jangka pendeknya menggunakan alat likuid yang dimiliki oleh bank tersebut dengan CR sebesar 22,96\%. Hal ini menunjukkan bahwa pada tahun 2015 cash ratio bank dikatakan sehat karena besar dari 4,05\%.

d. Tahun 2016

$$
C R=\frac{6.650 .475}{28.419 .940} X 100 \%=23,00 \%
$$

Artinya, bank mampu memenuhi utang jangka pendeknya menggunakan alat likuid yang dimiliki oleh bank tersebut dengan CR sebesar 23,00\%. Hal ini menunjukkan bahwa pada tahun 2016 cash ratio bank dikatakan sehat karena besar dari 4,05\%.

e. Tahun 2017

$$
C R=\frac{10.529 .761}{34.714 .102} X 100 \%=30,33 \%
$$

Artinya, bank mampu memenuhi utang jangka pendeknya menggunakan alat likuid yang dimiliki oleh bank tersebut dengan CR sebesar 30,33\%. Hal ini menunjukkan bahwa pada tahun 2017 cash ratio bank dikatakan sehat karena besar dari 4,05\%.

\section{Quick Ratio}

Quick Ratio (Rasio Lancar) menurut Faizal (2014) merupakan rasio yang menunjukkan kemampuan aktiva lancar bank yang paling likuid mampu menutupi hutang lancarnya.

QR merupakan kemampuan suatu perusahaan dalam menggunakan aktiva lancar untuk menutupi utang lancarnya. Semakin besar rasio ini semakin baik, rasio ini disebut juga sebagai Acid Test Ratio (ATR). Idealnya QR adalah $100 \%$ atau $1: 1$ dan minimalnya adalah $80 \%$ atau $0,8: 1$. Jika QR berada dibawah standar yang telah ditetapkan maka dianggap kurang baik tingkat likuiditasnya. Berdasarkan data yang diperoleh QR PT.BPR lengayang selama tahun 2013-2017 dapat dilihat pada tabel dibawah ini: 
Tabel 3

Perkembangan Quick Ratio PT. BPR Lengayang

Tahun 2013-2017

(Dalam Juta Rupiah)

\begin{tabular}{cccccc}
\hline Uraian & $\mathbf{2 0 1 3}$ & $\mathbf{2 0 1 4}$ & $\mathbf{2 0 1 5}$ & $\mathbf{2 0 1 6}$ & $\mathbf{2 0 1 7}$ \\
\hline $\begin{array}{c}\text { Alat Likuid: } \\
\text { Kas }\end{array}$ & 807.349 & 1.038 .498 & 617.874 & 509.424 & 495.817 \\
& & & & \\
Hutang lancer & 66.684 & 133.160 & 79.436 & 76.010 & 379.498 \\
\hline \multicolumn{5}{l}{ Sumber : Laporan Keuangan PT. BPR Lengayang }
\end{tabular}

Dengan Rumus :

$Q R=\frac{A L}{H L} X 100 \%$

Alat Likuid $\quad=$ Kas

Hutang Lancar = Kewajiban Segera

a. Tahun 2013

$Q R=\frac{807.349}{66.684} X 100 \%=1.210,70 \%$

Berdasarkan perhitungan diatas hasil QR adalah sebesar $1.210 .70 \%$. Artinya, bank mampu dalam membayar kewajibannya dengan menggunakan alat likuid yang dimiliki oleh bank. Hal ini baik bagi bank, karena QR berada diatas $100 \%$.

b. Tahun 2014

$Q R=\frac{1.038 .498}{133.160} X 100 \%=779,89 \%$

Berdasarkan perhitungan diatas hasil QR adalah sebesar 779.89\%. Artinya, bank mampu dalam membayar kewajibannya dengan menggunakan alat likuid yang dimiliki oleh bank. Hal ini baik bagi bank, karena QR berada diatas $100 \%$.

c. Tahun 2015

$$
Q R=\frac{617.874}{79.436} X 100 \%=777.83 \%
$$

Berdasarkan perhitungan diatas hasil QR adalah sebesar $777.83 \%$. Artinya, bank mampu dalam membayar kewajibannya dengan menggunakan alat likuid yang dimiliki oleh bank. Hal ini baik bagi bank, karena QR berada diatas $100 \%$.

d. Tahun 2016

$Q R=\frac{509.424}{76.010} X 100 \%=670,21 \%$

Berdasarkan perhitungan diatas hasil QR adalah sebesar 670,21\%.

Artinya, bank mampu dalam membayar kewajibannya dengan menggunakan alat likuid yang dimiliki oleh bank. Hal ini baik bagi bank, karena QR berada diatas $100 \%$. 
e. Tahun 2017

$$
Q R=\frac{495.817}{379.498} X 100 \%=130.65 \%
$$

Berdasarkan perhitungan diatas hasil QR adalah sebesar $130.65 \%$.

Artinya, bank mampu dalam membayar kewajibannya dengan menggunakan alat likuid yang dimiliki oleh bank. Hal ini baik bagi bank, karena QR berada diatas $100 \%$.

\section{LDR}

Pengertian Loan to Deposit Ratio (LDR) menurut Zebua (2014) menyatakan bahwa : "Loan to Deposit Ratio adalah rasio untuk mengetahui kemampuan bankdalam membayar kembali kewajiban kepada nasabah yang telah menanamkan dananya dengan kredit-kredit yang telah diberikan kepadapara debiturnya."

LDR dipakai untuk melihat kesanggupan bank membayar kembali penarikan yang dilakukan nasabah deposan melalui kredit yang diberikan sebagai sumber likuiditasnya.

Dari uraian diatas diketahui bahwa LDR merupakan kesanggupan Bank dalam melunasi kembali dana penarikan yang telah dilakukan deposan menggunakan kredit yang diberikan bank dengan menggunakan kredit yang diberikan bank dengan dana yang diterimah oleh bank.

Kriteria penilaian Cash Ratio menurut SK DIR BI Nomor : 30/12/KEP/DIR tanggal 30 april 1997 tentang tata cara penilaian tingkat kesehatan BPR (Taufik, 2012).
a. $<=94,75 \%$
: Sehat
b. $>94,75 \%-<=98,50 \%$
:Cukup sehat
c. $>98,50 \%-<=102,25 \%$
: Kurang sehat
d. $>102,25$
: Tidak sehat

Dari data yang diperoleh, loan to deposit ratio PT. BPR Lengayang tahun 2013 - 2017 dapat ditunjukkan pada tabel dibawah ini.

\section{Tabel 4}

Perkembangan Loan To Deposit Ratio PT. BPR Lengayang Tahun 2013 - 2014

( Dalam Juta Rupiah )

\begin{tabular}{lcllll}
\hline \multicolumn{1}{c}{ Uraian } & \multicolumn{1}{c}{$\mathbf{2 0 1 3}$} & \multicolumn{1}{c|}{$\mathbf{2 0 1 4}$} & \multicolumn{1}{c}{$\mathbf{2 0 1 5}$} & \multicolumn{1}{c}{$\mathbf{2 0 1 6}$} & \multicolumn{1}{c}{$\mathbf{2 0 1 7}$} \\
\hline $\begin{array}{l}\text { a. Kredit Yang } \\
\text { Diberikan }\end{array}$ & 25.903 .700 & 25.955 .264 & 26.587 .912 & 28.451 .020 & 31.748 .298 \\
b. DPK & & & & & \\
Tabungan & 8.560 .274 & 10.046 .391 & 11.495 .058 & 14.060 .430 & 17.961 .404 \\
Deposito & 8.420 .816 & 9.005 .700 & 12.182 .500 & 14.283 .500 & 16.373 .200 \\
Modal & 3.501 .500 & 3.617 .000 & 3.617 .000 & 3.817 .000 & 5.217 .000 \\
$\quad$ Jumlah & $\mathbf{2 0 . 4 8 2 . 5 9 0}$ & $\mathbf{2 2 . 6 6 9 . 0 9 1}$ & $\mathbf{2 7 . 2 9 4 . 5 5 8}$ & $\mathbf{3 2 . 1 6 0 . 9 3 0}$ & $\mathbf{3 9 . 5 5 1 . 6 0 4}$ \\
\hline
\end{tabular}

Sumber : Laporan Keuangan PT. BPR Lengayang

Dengan Rumus :

$L D R=\frac{\text { Total Loans }}{\text { Total Deposit }} X 100 \%$

Total Loans $=$ Kredit yang diberikan

DPK $=$ Tabungan + Deposit + Modal 
a. Tahun 2013

$$
L D R=\frac{25.903 .700}{20.482 .690} \times 100 \%=126,47 \%
$$

Dari uraian diatas dapat diketahui bahwa bank tidak sanggup membayar penarikan dana yang dilakukan nasabah menggunakan kredit yang diberikan dengan dana yang diterima bank sebesar 126,47\%. Ini menyatakan bahwa tahun 2013 PT. BPR Lengayang dikatakan tidak sehat, karena berada pada posisi $>102,25 \%$. yang ditetapkan oleh BI.

b. Tahun 2014

$$
L D R=\frac{25.955 .264}{22.669 .091} \times 100 \%=114.50 \%
$$

Dari uraian diatas dapat diketahui bahwa bank tidak sanggup membayar penarikan dana yang dilakukan nasabah menggunakan kredit yang diberikan dengan dana yang diterima bank sebesar $114,50 \%$. Ini menyatakan bahwa tahun 2014 PT. BPR Lengayang dikatakan tidak sehat, karena berada pada posisi $>102,25 \%$. yang ditetapkan oleh BI.

c. Tahun 2015

$$
L D R=\frac{26.587 .912}{27.294 .558} \times 100 \%=97,41 \%
$$

Dari uraian diatas dapat diketahui bahwa bank sanggup membayar penarikan dana yang dilakukan nasabah menggunakan kredit yang diberikan bank dengan dana yang diterima bank sebesar 97,41\% . Ini menyatakan bahwa tahun 2015 PT. BPR Lengayang dikatakan sehat, karena berada pada batasan $<=94,75 \%$ yang telah ditetapkan oleh BI.

d. Tahun 2016

$$
\begin{aligned}
L D R= & \frac{28.451 .020}{32.160 .930} \times 100 \%=88,46 \% \\
& \text { Dari uraian diatas dapat diketahui bahwa bank sanggup }
\end{aligned}
$$
membayar penarikan dana yang dilakukan oleh nasabah menggunakan kredit yang diberikan bank dengan dana yang diterima bank sebesar 88,46\%. Ini menyatakan bahwa tahun 2016 PT. BPR Lengayang dikatakan sehat, karena berada pada batasan $<=94,75 \%$ yang telah ditetapkan oleh BI.

e. Tahun 2017

$$
L D R=\frac{31.748 .298}{39.551 .604} X 100 \%=80,27 \%
$$

Dari uraian diatas dapat diketahui bahwa bank sanggup membayar penarikan dana yang dilakukan oleh nasabah menggunakan kredit yang diberikan bank dengan dana yang diterima bank sebesar 80,27\%. Ini menyatakan bahwa tahun 2017 PT. BPR Lengayang dikatakan sehat, karena berada pada batasan $<=94,75 \%$ yang telah ditetapkan oleh BI. 
Dari analisis cash ratio diatas secara keseluruhan dapat disimpulkan, bahwa CR yang diperoleh PT.BPR Lengayang setiap tahunnya mampu dalam memenuhi kewajibannya, hal ini baik bagi bank. Namun dari sisi pengelolaan dananya, masih terlihat banyak dana yang menganggur atau idle money. jika dalam cash ratio alat likuid tetap saja besar setiap tahunnya, maka akan berdampak buruk juga bagi bank, karena banyaknya dana yang mengendap. Oleh karena itu, sebaiknya bank menyalurkan kembali dana tersebut dalam bentuk kredit maupun investasi yang dapat menambah pendapatan bank tersebut.

Berdasarkan analisis diatas dapat simpulkan bahwa hasil QR setiap tahunnya berada diatas standar yang telah ditetapkan yaitu 100\%. Hal ini membuktikan bahwa PT. BPR Lengayang dalam keadaan likuid, karena bank mampu menutupi kewajibannya dengan menggunakan alat likuid yang dimilki oleh bank tersebut. Akan tetapi, jika dilihat dari tahun 2013 - 2017 QR bank berada di posisi terlalu tinggi, dari segi pengelolaan dananya, bank memiliki aset lancar yang sangat banyak sehingga dapat menimbulkan idle money atau disebut juga dana menganggur. Hal ini tentunya tidak baik bagi bank, karena dapat memberikan efek pada profitabilitas bank.untuk itu bank dapat menyrdiakan aset sesuai dengan kebutuhan dan sisanya bank dapat menyalurkan kembali aset tersebut bentuk pemberian kredit kepada nasabah yang dapat meningkatkan profitabilitas bank.

Dari analisis diatas dapat simpulkan bahwa hasil LDR bank pada tahun 2013 dan tahun 2014 menunjukkan bahwa bank berada pada posisi tidak sehat, karena berada pada batasan $>102,25 \%$. Sedangkan tahun 2015 - tahun 2017 bank mampu membayar kembali dana yang dilakukan oleh nasabah dengan menggunakan kredit yang diberikan bank dengan dana yang diterima oleh bank. Hal ini dibuktikan dengan perhitungan LDR pada tahun tersebut berada pada batas $<=94,75 \%$ yang artinya bank berada pada posisi sehat.

\section{SIMPULAN}

Berdasarkan hasil analisis pada bab sebelumnya, gambaran tingkat likuiditas PT. BPR Lengayang selama periode tahun 2013-2017 dapat disimpulkan bahwa :

1. Untuk Cash Ratio (CR) PT. BPR Lengayang pada tahun 2013-2017 berada pada posisi sehat, karena berada diatas standart yang telah ditentukan oleh BI. Hal ini menunjukkan bahwa bank mampu dalam membayar kembali simpanan nasabahnya jika nasabah tersebut melakukan penarikan terhadap uangnya yang tersimpan di bank.

2. Pada quick ratio (QR), PT. BPR Lengayang tahun 2013-2017 berada dalam posisi sehat atau dapat dikatakan bank mampu dalam membayar kewajiban jangka pendeknya, menggunakan aktiva lancar yaitu kas yang dimiliki bank tersebut.

3. Pada Loan To Deposit Ratio (LDR), PT. BPR Lengayang di tahun 2013-2014 dapat dikatakan tidak sehat, karena LDR berada pada posisi > 102,25\%. Namun pada tahun selanjutnya bank selalu mengalami perubahan yang semakin membaik, sehingga di tahun 2015-2017 bank berada pada posisi sehat. 


\section{UCAPAN TERIMA KASIH}

Terimakasih penulis sampaikan kepada :

1. Kedua Orang Tua yang senantiasa memberikan dukungan baik secara moril maupun materil.

2. Direktur AKBP beserta prodi AKBP yang telah memberikan kesempatan kepada penulis untuk melakukan penelitian ini.

3. Dosen Pembimbing tugas akhir yang telah memberikan arahan dan bimbingan hingga tugas akhir ini bisa terselesaikan.

4. Pimpinan PT. BPR Lengayang yang telah mengizinkan penulis dalam memperoleh informasi beserta pengambilan data.

5. Semua Pihak yang telah memberikan dukungan dan bantuannya dalam penyelesaian tugas akhir ini.

\section{DAFTAR PUSTAKA}

Afriyeni, A. (2017). Profitabilitas Bank Perkreditan Rakyat Di Kota Padang di Tinjau Dari Rasio Likuiditas. Jurnal Benefita, 2(1), 22-32.

https://doi.org/10.22216/jbe.v2i1.2104 Kop

Anggraeni, R. K., \& Dkk. (2014). Analisis Pengelolaan Kredit Untuk Meningkatkan Likuiditas dan Profitabilitas PT BPR Wlingi Pahala Pakto. Jurnal Administrasi Bisnis, 12(2), 1-10.

Arifin, I. Z., \& Marlius, D. (2017). Analisis Kinerja Keuangan PT. Pegadaian Cabang Ulak Karang. https://doi.org/10.31227/osf.io/n2peu

Faizal, C. (2014). Pengaruh Rasio Likuiditas, Rasio Profitaabilitas, Rasio Aktivitas, Rasio Solvabilitas, dan Rasio Nilai Pasar Terhadap Return Saham. Fakultas Ekonomi Universitas Negeri Yogyakarta.

Jumingan. (2006). Analisis Laporan Keuangan. Edisi Pertama. Cetakan Pertama. Jakarta: PT. Bumi Aksara.

Handayani, M., \& Marlius, D. (2017). Analisis Tingkat Kesehatan PT. BPR Batang Kapas. https://doi.org/10.31227/osf.io/bq48z

Ottay, M. C., \& Alexander, S. W. (2015). Analisis Laporan Keuangan Untuk Menilai Kinerja Keuangan pada PT. BPR Citra Dumoga Manado. Jurnal Emba, 3(1), 923-932.

Palar, D. S., \& Dkk. (2013). Analisis Tingkat Kesehatan PT. Bank SULUT, Tbk Dengan Menggunakan Rasio Keuangan, (10), 1-10.

Putri, Y. A., \& Marlius, D. (2018). Analisis Tingkat Kesehatan Bank Pada PT. Bank Perkreditan Rakyat (BPR) Jorong Kampuang Tangah Pariaman Cabang Padang. https://doi.org/10.31227/osf.io/r98pv 
Rahmayeli, D. S., \& Marlius, D. (2017). Analisis Kinerja Keuangan Pada PT. Bank Perkreditan Rakyat (BPR) Batang Kapas Pesisir Selatan. https://doi.org/10.31227/osf.io/sz5db

Ramadaniar, B., \& Dkk. (2013). Analisis Rasio Keuangan Perbankan Untuk Menilai Kinerja Keuangan Bank. Jurnal Administrasi Bisnis (JAB), 1(1), 49-58.

Susanto, H., \& Kholis, N. (2016). Analisis Rasio Keuangan Terhadap Profitabilitas Pada Perbankan Indonesia. Jurnal Ebbank, 7(1), 11-22.

Tanor, M. O., \& Dkk. (2015). Analisis Laporan Keuangan Dalam Mengukur Kinerja Keuangan Pada PT. Bank Artha Graha Internasional, Tbk Financial. Jurnal Emba, 3(3), 639-649.

Taufik, A. D. (2012). Analisis Penilaian Tingkat Kesehatan BPR Hasa Mitra Dengan Metode CAMEL. Manajemen Universitas Hasanuddin Makassar.

Undang-Undang RI No. 10. (1998). Undang-Undang Repulik Indonesia No. 10 Tahun 1998 Tentang Peubahan Atas Undang-Undang No. 7 Tahun 1992 Tentang Perbankan.

Yusra, I. (2016). Kemampuan Rasio Likuiditas dan Solvabilitas Dalam Memprediksi Laba Perusahaan. Jurnal Benefita, 1(September), 15-23.

Zebua, Y. (2014). Analisis Likuiditas Bank Mandiri Tahun 2009-2013. Jurnal Ecobisma, 1(2), 19-25. 